An International Journal of Language, Literature and Gender Studies (LALIGENS)

Ethiopia

Vol. 3 (2), Serial No 8, May, 2014:47-65

ISSN: 2225-8604(Print) ISSN 2227-5460 (Online)

http://dx.doi.org/10.4314/laligens.v3i2.4

\title{
THE IMAGE OF AFRICA AND AFRICANS IN SELECTED ANGLOPHONE EXPATRIATE NOVELS
}

\author{
IFEJIRIKA, E. ECHEZONA, Ph.D. \\ Department of English \\ Anambra State University, Igbariam \\ E-mail: echeifejirika@yahoo.com \\ Phone: +2348037426884.
}

\section{Abstract}

The spate of tremendous catastrophic upheavals in the world today, the high rate of pockets of ethnic and sectarian violence and a retrospective insight into the first World War (1914 - 1918), second World War, (1939-1945) and the September, 11, 2001, bombing and total destruction of the World Trade Centre (WTC) and the Pentagon in the United States of America by Osaman Bin Laden and his Al Qaeda group that led to great loss of lives and property, (all the deadly actions perpetrated by people whose skin is not black) necessitate a compelled revisit to Expatriates' novelists perception and depiction of Africa as a dark continent, a cursed geographical region infested by deadly animals and Africans as mature devils, halfwits, adult-children and sub-human beings who are bound to violence; and as people who lack comprehensible language, authentic history, 
workable economic and political system and whose religion is a compendium of paganism, atheism, polytheism, animism and necromancy; people who are often found quarrelling, laughing, crying or fighting. This study therefore reveals the unbelievable, shocking and derogatory perception and depiction of Africa and Africans in selected expatriate novels. It shows that Africans do not possess the monopoly of violence and animalistic tendencies.

\section{Introduction}

Prior to the emergence of Modern African Literature, Expatriate explorers, missionaries, colonial administrators and military adventurers had formed a pre-conceived and imaginary opinions and impressions about Africa as a continent and Africans as a distinct people. Before some of the Expatriates came to Africa for very many reasons, they had heard and believed the negative stories told by African "friendly enemies" that "Africa is a dark continent and the white man's potential graveyard."

It was described as a continent infested with wild dangerous animals and insects such as snakes, lions, pythons and mosquitoes as big as butterflies. Similarly, Africans were seen as people bound to violence, and who were embodiment of barbarism, cultism, abject-poverty, high level idiocy, paganism, primitivism, sorcery, cannibalism, witchcraft and necromancy. Some expatriates also reported falsely that Africans had tails like monkeys and had dark, sticky, repulsive and gummy colour that looked abominable.

Similarly, Africans were seen as mental liliputs or dwarfs, halfwits, adult-children and emotional idiots who often engaged in crying, weeping laughing or quarrelling. These eccentric and racially engendered ideas about Africans were manufactured and marketed essentially by Eurocentric literary expatriates, who perhaps wrote with the intention of expressing the magnitude of the work they had to do in Africa and on Africans and the urgency of civilization which Africa and Africans needed. It is interesting to note that the expatriate writers of literary works about Africa and Africans, employed setting and 
characterization as a means of accomplishing their derogatory portrayal of Africa and its inhabitants. For example, Charles Nnolim commented seriously about critics uncritical acceptance of Joseph Conrad's setting of his novel: Heart of darkness. According to Charles Nnolim:

Heart of Darkness has been interpreted symbolically as enacting man's descent to Hell, without critic's taking time to examine the actual life-setting or the biographical and historical sources of the story. For instance, Heart of Darkness, Conrad tells us in the Author's note "is experience pushed a little beyond the actual facts of the case for the purpose of bringing it home to the minds and bosoms of the readers." (22)

Nnolim blames critics for easily adopting the obvious exaggerations in the Heart of Darkness even when the writer, Joseph Conrad, had himself, acknowledged his intentional hyperbole in the novel. No wonder Nnolim referred to the "biographical and historical sources" of the novel as obviously written by "a friendly enemy."

A similar perception of Africa as a dark continent was expressed by king Leopold II of Belgium, who after the Berlin Conference of 1884, after the balkanization of Africa for European nations, opined that their aim (colonialists) was:

To open to civilization the only part of our globe (Africa) where Christianity has not penetrated and to pierce the darkness which envelopes the entire population (Nnolim, in Pessimism as Dialectic; 22)

For Leopold, who was reported to be notoriously, commercially inclined and shamelessly exploitative, Africa was the only continent where Christianity had not reached, and to that extent, darkness enveloped everything in Africa and it was the avowed duty of the Balgians to bring light to Africa. 
So one is not therefore surprised when Henty, an expatriate literary artist wrote concerning Africa and Africans from a paternal perspective and mockingly presented Africa and her people thus:

Africans are like children... they are always either laughing or quarrelling. They are good natured and passionate, indolent, but will work hard for a time; clever up to a certain point, densely stupid. The intelligence of an average Negro (blacks) is about equal to that of a European child of ten years old...They are absolutely without originality, absolutely without inventive power. Living among white men, their imitative faculties enable them to attain a considerable amount of civilization. Left alone to their devices, they retrograde into a state little above their native savagery (21).

For want of space, we summarize Henty's perception and description of Africans as derogatory, diminutive, racial and dehumanizing. Though he generously granted Africans humanity, he mercilessly denied them any worthwhile personality and identity as human beings.

Before we conclude this introductory part of the paper, the racial views of another expatriate writer, Mary Gaunt, are stated to accentuate our views on the derogatory and racial perception of Africans by "the beacons of light and salvation." According to her:

Man was given intellect that he might have dominion over the forces which uphold the universe as well as the herb and beast and no mere animal courage backed by straining effort of splendid muscle can compete with the White man's intelligence, which holds in subjection, roaring fire and tireless steel. So once more, through massive body and perfect limb, the savage (black) was beaten (21). 
The point Mary Gaunt is making is that the white man, through superior intellectual endowment, subdued the untamed universe and its devilish contents, including the black man who uses more of his hand than his head, that is, physical instead of mental capacity.

In the subsequent part of this study, some novels of Joseph Conrad, Graham Green, and Joyce Cary are critically studied with a view to pointing out the expatriates' perception and portrayal of Africa and Africans in the most racial, unfriendly, derogatory and abusive manner.

\section{The Setting of the Eurocentric African Novels}

The first aspects of some of the novels chosen for this study that would interest a critical reader are the titles and the settings. For example, for Joseph Conrad, the novel: Heart of Darkness conveys an obvious message; the setting of the novel is in the darkest part of the world or put simply, "Heart of Darkness." According to the author, Heart of Darkness is:

A venture into the interior, a passage to Africa, a nongeographical spot and a colossal jungle, dark green, black and fringed with surf, a prehistorical earth and aspects of unknown planet... The air above grave sand is dark mournful, gloom brooding and motionless, the environment dirty, fiendish infested with buzzing flies and deadly mosquitoes, a God forsaken place, causing people to die untimely.

A critical study of the novelist's diction in describing Africa, the setting of Heart of Darkness sends cold shivers, disgust and repulsion in the mind of the reader. No wonder Chinua Achebe, in commenting on the darkening and frightening geographical background or setting of the novel observes:

Heart of Darkness projects the image of Africa as the other world. The antithesis of Europe and therefore of civilization, a place where man's vaunted intelligence 
and refinement are finally mocked by triumphant bestiality... The actual story took place on River Congo, the very antithesis of the Thames. The River Congo is quite decidedly a river Emeritus. It has rendered no service and enjoys no old age pension. We are told that going up the river was like travelling back to the earliest beginning of the world.

Achebe's argument is that the setting of the novel is derogatory because a river that should serve as a source of life appears deadly and a journey through it is a reversal or backward movement. In commenting about Joseph Conrad's setting of his novels, Charles Nnolim observes:

Although a novelist usually sets extraordinary people in ordinary circumstance, or ordinary people in extra ordinary backgrounds, in the latter case the background is seldom as brooding and self-defeating as we find in Conrad's works (15).

This observation concerning the frightening and defeating nature of Conrad's literary settings in Africa is contained in Nnolim's article entitled: "Setting: The Theatre of Pejorism."

In a similar vein, Joyce Cary's novel: The African Witch (1936) is unpretentious about its derogatory title and its repulsive setting. The African Witch is set in a town called Rimi in Northern Nigeria. The town is infested with intrigues, violence and betrayals. The major characters are set against one another in bitter and violent conflicts. The people are obviously engaged in witchcraft.

In addition, the novels of Graham Green, another expatriate novelist, give a pejorative setting that portrays Africa in a bad light. In some of his novels; Heart of the Matter (1948) Journey without Maps (1936) A Burnt out Case (1961) In Green's Journey without Maps, for example, the title implies that Africa is not in a world map, a journey into Africa is a journey through the dark forests, a journey without 
direction. For example, a journey without maps, just like a flight without compass leads to no known destination and to disaster.

The novel Journey without Maps concerns itself with the assessment of international cultural relationships. There is condemnation, scorn, mockery and denigration of other people's cultures in comparison with European culture. The novel is set in Liberia. The country is described as a bush, bedevilled with secret societies. One white character, Lamina, in reference to Africans, said: "The people bad, they chop man." Green shares his character's assessment of Africa and Africans, when he says:

Civilization is synonymous with exploitation of Liberia. We have not improved the natives at all... they still drink polluted water and suffered from some worms (61)

There is no doubt that Graham Green was greatly influenced by Joseph Conrad's frightening stories about Africa in his earlier novels. Before Green arrived in Liberia, he had heard and read stories that were profoundly frightening about Africa and her primitive inhabitants. For example, he had read that:

The rat population in Monrovia (capital of Liberia) may be fairly described as swarming, the wood and corrugated houses lent themselves to rat harborage, and that mosquitoes caught in Monrovia are of a species known to carry yellow fever. (17)

From the above, Green portrays the entire country as being infested with rats, bats, ants, mosquitoes, moths, beetles and deadly snakes. No wonder Green expresses strong admiration for the Catholic Church and their missionaries who courageously faced and endured the risk of fever, snakes, worms and rats in the course of their evangelism in Monrovia. In effect, the overall picture created in Journey without Maps is akin to the image of Darkness, because when one travels without maps, one is in total darkness. As Green puts it, Journey 
without Maps is an adventurous journey for those who are, "willing to suffer some discomfort for the chance of finding."

So, from the point of setting or literary background, most of the novels written by expatriates in and about Africa portray the continent in the most pejorative, diminutive, derogatory and embarrassing pictures; aimed at creating the ugly impression that the continent is uninhabitable and that the expatriates had come to salvage her at extreme sacrifices.

\section{The Characterization of Africans in the Novels}

At the university, I read some appalling novels about Africa (including Joyce Cary's Mr. Johnson) and decided that the story we had to tell could not be told for us by anyone else, no matter how gifted or well intentioned (70).

It is in the light of the above excerpt from Chinua Achebe's Morning Yet on Creation Day, where he expresses great disappointment with the appalling and derogatory image of Africa and Africans in Eurocentric novels (which served as a springboard to the writing of his early novels) that this study illuminates the perception and characterization of Africans in the novels chosen for this research. This section of the study critically examines Joseph Conrad, Joyce Cary and (Graham Green and their Characterization of Africans in Heart of Darkness, The African Witch, Mr. Johnson and Journey Without Maps, respectively. Some brief references are made to other expatriate novels other than the ones listed above to accentuate our view.

Apart from the derogatory and bleak setting, Expatriate novelists employed characterization as another means of pouring their venom of racism, racial prejudice and denigration on Africa and Africans. For example, below is a long excerpt from Joseph Conrad's perception of the Africans he met in his novel and the unviable environment in which he found them. The quotation is fairly lengthy but apt to 
espouse the point being made. According to his reports in the Heart of Darkness:

We penetrated deeper and deeper into the heart of Darkness (African country). It was very quiet there. We were wanderers on a pre-historic earth, on an earth that wore the aspect of an unknown planet. We could have fancied ourselves the first of men taking possession of an accursed inheritance, to be subdued at the cost of profound anguish and of excessive toil. But suddenly as we struggled round a bend, there would be a glimpse of rush walls, of peaked grass roots, a burst of yells, a whirl of black limbs, a mass of hands clapping, of feet stamping, of bodies swaying, of eyes rolling, under the droop of heavy and motionless foliage... The prehistoric man (an African) was cursing us, praying to us, welcoming us - who could tell? We were cut off from the comprehension of our surroundings; we glided past like phantoms, wondering and secretly appalled as sane men would be before an enthusiastic outbreak in a madhouse. We could not understand because we were too far and could not remember, because we were travelling in the night of first ages, of those ages that are gone, leaving hardly a sign - and no memories. The earth seemed unearthly. We are accustomed to look upon the shackled form of a conquered monster, but there - there you could look at a thing monstrous and free. It was unearthly and the men were no, they were not inhuman. Well, you know that was the worst of it - this suspicion of their being inhuman. They howled and leaped, and spun and made horrid faces; but what thrilled you was just the thought of their humanity - like yours the thought of your remote Kingship with this wild and passionate 
uproar. Ugly yes, it was ugly enough... there was a suspicion of there being a meaning in it which you so remote from the night of first ages, could comprehend. (PP.63-64)

Let us briefly but critically summarize Joseph Conrad's racial venom and hatred on Africa and Africans in the long excerpt by picking some of his appalling and repulsive diction that paints Africa and Africans as the "Heart of Darkness." Some of the miserable and diminutive terms used by the author to describe the black people he met and the environment in which he met them include: "Heart of Darkness", "prehistoric earth", "an earth that wore an aspect of unknown planet", "an accursed inheritance", rushed "walls and peaked grass roots", "burst of yells", (for African language,) "black limbs and mass of hands", (that describe Africans), "an enthusiastic outbreak in a madhouse", (that describes African languages), "in the night of first ages", "The earth seemed unearthly," "shackled form of a conquered monster" (Africans), "a thing monstrous and free" (Africans), "suspicion of their being in human" (perhaps baboons) "the thought of their humanity like yours" (describing Africans), "ugly, yes, it was ugly enough" (Africans).

To Conrad, Africans were so ugly and insignificant that he denied them identity and humanity. He saw them as limbs and hands, perhaps without heads and sense faculties. No wonder he was in dilemma whether to accord them human status or not. He even wondered whether the limbs and mass hands were cursing them, welcoming them or praying to them as they (whites) appeared like gods in their "golden and crystal-like" colours. The Africans, whom Conrad and his crew met, were clapping hands, stamping feet, swaying bodies and rolling their eyes, while living "under the droop of heavy and motionless foliage."

What really worried Conrad most was "the thought of their remote kingship with this wild and passionate uproar but was however consoled by their obvious remoteness from the night of the first ages", 
where Africans still find themselves. The only African whom Conrad identified as a human being lacked identifiable features such as name, height and colour. He was simply described as a savage who manifested idiotic tendencies in thought and action. Joseph Conrad described the African thus:

And between whiles I had to look after the savage who was fireman. He was an improved specimen; he could fire up a vertical boiler; he was there below me and upon my word, to look at him was as edifying as seeing a dog in a parody of breeches and a feather hat walking on his hind legs. A few months of training had done for that really a fine chap. He squinted at the steam-gauge and at the water gauge with an evident effort of intrepidity. And he had filed his teeth too, the poor devil and the wool of his pale shaved into queer patterns, and three ornamental scars on each of his cheeks. He ought to have been clapping his hands and stamping his feet on the bank, instead of which he was hard at work, a thrall to strange witchcraft full of improving knowledge he was useful because he had been instructed (64).

Joseph Conrad's diction in describing the African is a manifestation of the profundity of his racial prejudice against Africans. He described the man as "the savage", "below me" (Conrad) and looking at the African amounts to "seeing a dog", "a poor devil", "a witch" with "queer patterns on his cheek", and he was "full of improving knowledge", "because he had been instructed", by the white man. Similarly, the Africans paddling canoes were described as "black, naked, dusty niggers", that "move about like ants", and their "faces like grotesque masks" (ugly masquerades).

And in the words of the novels protagonist, Charles Marlow, the colonialists' objective in Africa was: 
To tear out the treasures out of the bowels of the land and the conquest of the earth means taking it away from those with different complexion or flat noses (63).

That is, the colonial interest of the expatriates in Africa was to exploit the land and the people whose physical features and colour were seen as abomination by the exploiters. The final repulsive description of Africans was made by Conrad, when he told the reader about the Africans who were rolling boats. According to him:

Now and then a boat from the shore gave one a momentary contact with reality. It was paddled by black fellows. You could see from afar the white of their eyeballs glistening. They shouted, sang; their bodies streamed with perspiration; they had faces like grotesque masks - these chaps but they had bones, muscles, a wild vitality; an intense energy of movement that was as natural and true as the surf along their coast. They want no excuse for being there. They were great comfort to look at. (41)

It is an unmitigated demonstration of racial prejudice to associate Africans with wild (animal) vitality, "grotesque faces", "bulging and glistening, white eyeballs", while performing normal duties. The blacks without names "were shouting and singing", and their bodies, "streamed and soaked with perspiration", and these mockingly make "them a great comfort to look at", instead of saying bluntly, "they were ugly and provocative sights to behold." And to show that Africans are animals, Marlow happily reported how they (Africans) gathered from the interior and coastal regions (perhaps for onward transportation to western plantations), were left to die instalmentally. According to Marlow:

They (blacks) were dying slowly. It was very clear. They were not enemies, they were not criminals; they were nothing earthly now, nothing but black shadows 
of disease and starvation lying confusedly in the greenish gloom. Brought from all the recesses of the coast in all the legality of time contracts, lost in uncongenial surroundings, fed on unfamiliar food, they sickened, became insufficient and were then allowed to crawl away and rest (68).

Even domestic animals are not starved as shown above. In the same vein, the most painful and prejudiced aspect of Conrad's Heart of Darkness is his intentional denial of Africans, of intelligible and mutual language. It is, perhaps, pertinent to remind the readers that what really distinguishes man from animals are his upright brain and the possession of language with semantic features. However, by Conrad's estimation, Africans shout, clap, stamp their feet like stammers and make "violent babble of unworthy sounds". This led Chinua Achebe to remark that, "It is clearly not part of Conrad's purpose to confer language on the rudimentary souls of Africa."

In another development African characters in Mr. Johnson and The African Witch are depicted as fools who reasoned a little above animals. They are set against one another through their witchcraft. The Emirs palace is notoriously noted for the practice of juju and witchcraft. Two characters, Osi and Ibu are accused of witchcraft and penalized for being witches. The duo are presented as innocent victims of a primitive, retrogressive and superstitious society with mundane belief and ideas. Through the depiction of the unmerited barbaric treatment given to Osi and Ibu, Cary makes a case that traditional African society is noted for miscarriage of justice, based on superstitious beliefs. Another character, Louis Aladai, the protagonist of the novels many unsuccessful attempts to befriend the Expatriate, Assistant Commissioner of Police, Captain Rackham, never produced any positive results, despite his being highly educated and trained in London. The whites in Rimi town preferred to deal with traditionalists instead of the educated class, whom they (whites) distrusted so much. Aladai's guts in mobilizing his fellow Africans against the white authority eventually led to his destruction. The reader is therefore not 
surprised that Louis Aladai's sister, Elizabeth succeeded where Aladai, in spite of his education, failed. Elizabeth, a juju priestess, was captured, imprisoned and was given poisoned chicken. She was heartlessly put into a hole to be devoured by hyenas. Miraculously she survived and escaped unhurt, perhaps through witchcraft.

Critically, the survival and success of the juju priestess whereas the educated African, Aladai, met his failure and waterloo symbolically means that the devil was still in charge in Africa. In the novel, a number of African characters were satirized. For example, the Emir, Aliu, is depicted as not being qualified to lead his people. He hated progress and development so much to the extent that he wanted the British Expatriate to banish Aladai and Sale out of Rimi town. According to Cary, the king said, if Aladai and Sale were not banished from Rimi, he himself would go away from Rimi town (76). He preferred darkness to light. For example, the Assistant Commissioner of Police in Rimi spoke the mind of the Expatriate novelists about Africa and Africans when he said:

The black out there are not fit to run their own show; and it will be a long time before they learn. Meanwhile we have got to keep the machine running, and the only peaceful way of doing that is to support white prestige (97).

In another novel entitled: Mr. Johnson, Joyce Cary presented the protagonist, Mr. Johnson, as an African whose actions portrayed high level of idiocy. His language is nearly incomprehensible and incomprehensive. He was presented as a caricature, and stereotype character, that was a little below humans and a little above animals. When Johnson is over burdened with debts and the pressure from his creditors, he spoke in extreme emotion and in a language that was hardly intelligible. He lamented in outburst:

Oh Gawd! Oh Jesus! I done finish - I done finish now. Mr. Johnson done finish - Oh Gawd, you no fit do nothing - Mr. Johnson too big dam fool - the fool 
chile - Oh my Gawd!... Why you so bloodly big dam fool, you Johnson? You happy for Fada - you catch good pay - you catch pretty girl - you catch nice gentlemen friends - you catch new shoes - you big man - now you play de bloody fool - you spoil everything (20).

So through Johnson, one comes to appreciate man's inability to understand himself and his actions and that of others. Johnson is an adolescent African clerk from a mission school and serves in British colonial administration in Nigeria. His ambition in life is to be like the Europeans in dressing, possession and speech/behaviour. And as a result, he is torn between two worlds - the traditional African culture and that of the Western world. Unfortunately, he has no strong hold in either. For example, from linguistic perspective, what Johnson speaks, as shown above, is neither Standard English nor transliterational variety of English. It can at best be classified as Pidgin English. Cary presents Johnson as an impostor and a notorious and shameless debtor, who deceives his wife Bamu to perceive him as a very rich man. He borrows money from people, asks for salary advance in the office and goes bankrupt before the end of each month. To demonstrate the profundity of his foolishness, despite the fact, that the whiteman sacked him from his work because he is involved in lies, cheating, deceit and exploitations, he still regards the whiteman as his best friend and confidant.

In the same negative depiction of Africans, the Waziri in Mr. Johnson is portrayed as someone that is allergic to development. For example, the Waziri opposes the building of a road across his community because of the tendency of roads to attract strangers and armed robbers to the community. It is only a foolish African leader that would stand against the construction of roads which usually attract visitors that assist in the physical and intellectual development of any town, city or nation. 
Finally, the fact that Johnson tells lies, borrows money from different people; takes salary advance, hosts lavish parties; saves nothing, collects bribe; regards his worst enemies as his best friends and is eventually arrested, tried and executed by his "best friends", go a long way to demonstrate the negative image and derogatory portrayal of Mr. Johnson as an African in the novel Mr. Johnson.

Similarly, the portrayal of Africans as toys in the hands of Expatriates and as fools who are daft enough not to know their enemies is accentuated by the fact that Africans who became friends to Expatriates are eventually killed by their "friendly-enemies". For example, in The African Witch, Louis Aladai is destroyed by his white friends in government in Mr. Johnson, Johnson is shot by Rudbeck whom he (Johnson) admired so much, imitated and worshipped. In Heart of Matter. Scobie (an Expatriate) killed his humble servant, whom he "loved" so much.

Similarly, in continuation of the poor perception of Africa by Expatriates in their novels, Graham Green, in Journey Without Maps (1936) depicts Africa as a continent that is hardly found in the world maps; a journey into Africa is a journey through dark forests; a journey in the darkest of the nights.

The novel concerns itself with international cultural relationships. In the novel, there is condemnation, scorn, mockery and denigration of African culture, perceived to be inferior to western culture. According to Lamina, a character in Journey Without Maps; "the people (Africans) bad, they chop man". In fact, the overall picture created by green in the novel is akin to the image of Africa in Conrad's Heart of Darkness because when one travels without maps, one is totally in darkness, destination wise, and The Heart of the Matter is darkness which breeds danger, posed by cannibals, mosquitoes, rats, snakes, bats, moths that directly or indirectly cause ultimate death of the white men in Africa. 
Therefore, "a journey without maps", is an adventurous journey for those who are "willing to suffer some discomfort for the chance of finding."

\section{Conclusion}

A critical observation of the magnitude of social upheavals, rampant cases of heartless acts of terrorism and inter/intra country strifes in Europe, Asia, Africa, the Middle East and other continents go a long way to show that Africa and Africans do not possess the monopoly of violence and are not bound to violence and idiocy as Expatriate writers, especially in literary works, perceived and depicted them.

Secondly, while no one can honestly and comfortably exonerate Africa and Africans from some of the expatriates' accusations of the continent with abundance of primitivity, cannibalism, idiotic tendencies, violence, animism, paganism and necromancy (among other deadly accusations), it is however clear that the devil is not as black as he is painted. Rather, it is obvious that the derogatory and diminutive manner in which the continent and her people were perceived and portrayed in expatriate novels is greatly influenced by racism, cultural prejudice and superiority complex. One is therefore not surprised when M.J.C Echeruo, a renowned Nigerian literary critic observed, with regard to the appalling image of African and Africans in Eurocentric novels. According to him:

Their main (Expatriates') concern is documenting, interpreting African situation from European point of view and exaggerating those aspects of Africa that distinguish it from the imagination of the Europeans (73).

In a nutshell, the perception and depiction of Africa and her people in Eurocentric novels by expatriates is based essentially on their imagination which is often exaggerated to satisfy the ego of expatriates as superhumans, agents of civilization and beacons of light, and to justify the exploitation of the people. 
Again, the expatriates' exploitative tendencies in Africa engineered their condemnation of the continent and the people with a view to concealing the profundity of their loots from the eyes of the natives and the wider world. Joseph Conrad himself acknowledged this when he wrote in his Author's Note to the present edition of Heart of Darkness:

It is well known that curious men go prying into all sorts of places (where they have no business) and come out of them with all kinds of "spoil." (pp. vi vii).

Gene M. Moore, in his introduction to the present edition of Heart of Darkness added his voice to Conrad's view above when he said:

These stories (in the expatriates' novels) tell of men who go beyond the normal routine of ordinary life to test themselves where they have no business, whether from curiosity or from necessity, and of illegitimate and deplorable kinds of "spoil" that result from such encounters. Conrad tells us not only of the spoil brought back, but also of the spoils left by the way side ( $\mathrm{p}$ vii).

So, in the novels, the expatriate novelists went beyond the actual settings, events, characters and characterization in painting the picture of Africa and Africans.

\section{Works Cited}

Achebe, Chinua. Morning Yet On Creation Day. London: Heinemann, 1982.

Cary, Joyce. The African Witch. London: Longman, 1936.

- - -. Mr. Johnson. London: Longman 1936.

Conrad, Joseph. Heart of Darkness and Other Stories. London: Wareheart, 1975. 
Echeruo, Michael. Joyce Cary and the Novel of Africa. London: Longman, 1973.

Green, Garham. Journey Without Maps. London: Heinemann, 2002.

- - -, The Heart of the Matter. London: Heinemann, 1984.

Nnolim, Charles. Morning Yet On Criticism Day. The Criticism of African Literature in the Twentieth Century. Port-Harcourt: University of Part-Harcourt Press, 2009.

Nweze, Emmanuel. Africa in French and German Fiction. Ile-Ife University Press, 1978. 